\title{
The Patterns of Sociocultural Adaptation of Migrants in The City of Ternate, North Maluku
}

\author{
Syamsiar \\ Department of Geography, Khairun University, Ternate, Indonesia \\ Corresponding author: syamsiarsamadd@gmail.com
}

\begin{abstract}
Studies on adaptation of migrants in a new urban environment have widely been explored by researchers from various perspectives and disciplines. Most of the studies focus on how migrants from socially less complex society, be it rural areas or less developed countries, adapt to a more complex urban or developed society. Although those studies offer significant contribution to our understanding on migrant adaptation, they do not address issues on how migrants from more complex society adapt in less complex urban setting. As a result, we do not have much knowledge on how the migrants from more complex social environment adapt to a less complex social environment. By interviewing migrants coming from big cities to the small city of Ternate, this study investigates the patterns of adaptation undertaken by migrants coming from socially more complex society to a socially less complex society. This study find that patterns of adaptation strategies carried out by migrants in Ternate is mainly related to the context specific problems they face in the Ternate city.
\end{abstract}

Keywords—migrant, adaptation, ternate, buginese.

\section{INTRODUCTION}

Many studies have been undertaken on migrants' adaptation to new situations. In general we get overload of studies focusing on adaptation of migrants from rural to urban [1]. Since the era of "social capital", many study on migrant's adaptation are related to social capital they have or develop in urban situation[5, 6, 7]. In other words, most of the previous studies on migration and migrant's adaptation mostly concentrate on migration and adaptation of migrants from small and less complex societies to big and complex societies.

It is interesting to see migration or migrants from different directions, from more complex societies to less complex societies. In line with this direction, this article is intended to answer the question of how migrants from more complex urban setting make adaptation in less complex urban setting. This study focuses on the case of adaptation of Buginese migrants from a big city of Makassar - South Sulawesi, in a small city of Ternate - North Maluku. The main focus is not on adaptation process in general but rather on adaptation to specific characteristics of small city of Ternate both to its unique social environment as well as its physical environment which are different from the migrants' previous environment in Makassar.

\section{RESEARCH METHOD}

A.

\section{Location and Sample}

This study is conducted in Ternate, a small city, but the most populous city in North Maluku Province. This study employs qualitative procedures, therefore the informants are chosen purposively based on criteria that they are migrants from Makassar, South Sulawesi. The purpose of the study is to find the patterns of adaptation performed by migrants coming from more complex urban society like Makassar in less complex urban setting like Ternate. For that purpose, seventeen migrants are interviewed during the fieldwork.

\section{B. Data Collection and Data Analysis}

Data are collected through interviews and observation. The interview is directed to explore their experiences as migrants in Ternate, kinds of problems they face, and how they deal with the problems. By doing that I can map the kinds of adaptations they undertake. Data is analyzed qualitatively using procedures offered by Miles and Huberman [8] which involve data reduction, data display, and drawing conclusions.

\section{RESULT AND DISCUSSION}

\section{A. Adaptation to Education}

In general, migrants and local people consider education quality in Ternate is lower than other cities in Indonesia. For some migrant with low educational background, they do not care about quality. They just register their children to any available schools and do not take any special steps to support their children academic achievement.

Buginese Migrants such as Ardiyansah, egg seller in traditional market. Although he did not finish his junior high school, he wants his children become educated and successful in the future. To achieve this expectation, he send his children to attend English course after school. He says "I want all my children become good and successful people in the future. I work hard for them, that is why I just don't think much about money I spend for their education. As far as I can afford to pay, I will pay for their education". It is obvious that Ardiansyah has high education aspiration. 
It is interesting that Ardiyansah's aspiration for his children has been developed since he was in Makassar, but his decision to send his two children to English course is made in Ternate. He hears from fellow migrants as well as local people that education quality in Ternate is lower than in other cities like Makassar.

What Ardiyansah has done are quite similar to what some other migrants as well as some local people with higher educational background have done. A couple, Amin and Ati, migrants from Makassar, register their children to private schools in Ternate. Since they think the quality of education is not as high as other cities in Indonesia, they have to spend time to teach their children as additional lessons at home. Ati says "we have to admit that the quality of schools rather lower that what we expect. Sometimes I ask questions to my children just to know how their knowledge, sadly they could not answer some, they don't know things that they should have known at schools". In dealing with this problem, Ati and his husband agree to give some additional lessons to their children at home.

The education quality is getting improving year by year but still under the expectation of some migrants families as well as some local people. A lecturer, a local people, whose wife is also local, says that they want to send their children to other city in Java or Makassar to have better quality education overthere.

\section{B. Adaptation to Expensive Life}

Migrants as well as local people have been facing expensive price in almost everything in Ternate. It is like permanent pattern that the more distance someone away from Jakarta (capital city of Indonesia) the more expensive things are, on the contrary the more he close to Jakarta the cheaper he find things. Ternate is quite far from Jakarta, and according to statistics releases by central bureau of statistics (BPS), data from 2014 to 2017 show that Ternate is the third most expensive cities in Indonesia after Jakarta and a city in Papua.

To cope with the expensiveness, the migrants have taken some different strategies. Bia, a house wife, says "when I first time went to local traditional market, was shock when I know that vegetables and spices were so expensive. I did not have any choice I had to buy them because I need them. Gradually I am getting used to such things, I am not shock anymore". Other migrants also tells almost the same stories about how expensive the price of food stuff in the market. Unlike Bia, Ati avoids buying cooked foods in the market. She instead cook at home for every meal needed by his husband and children. She says "it can save money, so the money can be used for other purposes".

Ati also takes other strategies to face expensive life in Ternate. She not only cooks for her family at home, Ati also sometimes make some cakes that she can sell in school where she teaches. In addition, sometimes she cooks for school's events. Besides, she also sells dresses she orders directly from her friend who has garment factory in Java. By ordering directly from factory, she cut much distribution cost, and for that reason she can sell with cheaper price compare with the price of the same objects in the shops in Ternate. This attract many buyers. Becce faces the expensiveness by not buying clothes in Ternate. She usually buys clothes when she go to other cities in Indonesia for office tasks. She also makes use of the land in front of her house to plant some vegetables, chilies, tomatoes, papaya, and some others.

The general trend of expensiveness in Ternate city also affects the price of house. The price of house increases significantly year by year, and this condition burdens not only the local people but also the migrants. It is impossible now to buy a livable house below Rp. 400 millions in the middle of the city, it was possible in five years ago. A house valued Rp. 500 million five to seven years ago will become at least 1,5 billion today. To deal with this, many migrants decide to buy houses in the peripheral areas of the city since their prices are not as expensive as the houses the around the center of the city. Asmah and her husband (her husband is a local man) buy land to build their house are called Kalumata Puncak (Kalumata is a village's name, and puncak means top of a mountain). According to Asmah, they intentionally bought land in that area because at that time it was still cheap. At the present, have been expensive but still less expensive than areas in the middle of the city. The same strategy is taken by Becce and his husband who decided to buy house in an area which is topographically higher above a village called Maliaro Puncak (Maliaro is a village name, puncak means top of a mountain). To reach that area, her vehicle should climb some height with a slope of about 30 to 40 degrees. From that area one can look at the city down as if he is on the top of a mountain. Amin and Ati bought a house in peripheral called Jere Busua (Jerbus), an area where the landscape is uneven.

\section{Adaptation to Physical Environment}

According to Central Bureau of Statistic - BPS (2017), Ternate's population growth rate in 2015 was 2,57\%. Due to rapid population growth which increase density on one hand whereas the city has limited living spatial on the other hand, housing development for growing needs of city dwellers stretches out to the marginal areas of the city. As a result, people both local and migrants have to adapt with this demographic and environmental development in the city. As described above, migrants have to make some adjustment to new uneven landscape in Ternate and in around their houses and neighborhood which differs topographically from their environment back home in their places of origin. Becce says "we need house to manage our own family but all houses in the middle of the city are too expensive, it is beyond our budget. The only way to have our own house is to get credit from a bank to buy house in this mountainous landscape".

She also says, "the first time we live in this house we find this is too far from the central of the city, moreover our motorcycle have to climb the mountainous landscape to reach this house. Yet, as time goes by everything becomes easier and we feel comfortable with this house". The only persistent 
problem they face in this mountainous area is lack access to clean water. Although, as a registered consumer they have paid monthly to district drinking water company (Perusahaan Daerah Air Minum - PDAM) for water but due to high landscape, frequently water cannot reach their house. In this situation, they must buy water from private water seller who can be called any time to bring water to their house. This kind of water seller usually sell water in this fringe zones of the city.

Other environmental problems migrants have to adapt with are the high frequency of earthquake in North Maluku including Ternate. Migrants experience this natural phenomenon differently. Amin and Ati with their children have no problem at all with this. As Ati explain "we had already experienced earthquake, even more frequent, in Japan during Mr. Amin study there. Therefore, we are not shock here, we had no problem with earthquake here". Bia says " at the first time I experienced it, I was so scare that I thought I wanted to leave Ternate. But, I saw other people are not shock, so I learn that it is not a big deal for most of the people here, so am I now."

Similar to earthquake is threat from volcano eruption. Ternate is located directly in the foot of Gamalama mountain, an active volcanic mountain. The mountain always releases some volcanic dust in almost every two years, and sometime followed by eruption. Ardiyansha says that he was scary in the first time because back home in Makassar there are no volcano. However, he and his family gradually accept it as a routine natural phenomena that they have to face in Ternate. Becce, another migrant, says "it was scary when for the first time I directly saw a volcano eruption, just in front of my eyes, not on TV". She expresses her feeling in more detail:

The sound of the eruption really shocked me, I was very shock. But I saw the neighbors, the local people, were calm and no signs of panic at all. They even make it a spectacle. So I thought oh it seemed harmless. And besides, I think if we have to take refugees, we are not alone, we are taking refuge with other people. Because eruption has happened several times since I moved here, I finally got used to it and consider it a normal thing, just like how the local people here see it.

\section{Adaptation to Language and Socio-cultural Life}

North Maluku is inhabited by around 33 indigenous ethnic groups, each of which has their own ethnic language[9], including Ternate language for Ternate ethnic group. These diverse ethnicity and language do not hinder them communicate each other by using bahasa Melayu Ternate. As other part if Indonesia where Melayu language was using as lingua franca, Melayu ternate language is also a lingua franca for local people from different ethno-linguistic backgrounds.

Migrants who come to Ternate find language is one obstacle for them in early period of their arrival in Ternate. Ati says "language is an important obstacle". Becce, Ati, Bia,
Ardiyansah, Amin, Dahlia, and Asma share similar experience on language adjustment. They said the more they involve in social activities involving themselves and local peoplethe easier they find to speak "melayu Ternate". Likewise, the more they can speak Malayu Ternate, the better their social networks expand. Dahlia says "since I can speak [Melayu] Ternate, I can easily take parts in various social and religious activities in campus where I study, in schools where I teach, and in community where I live. Friends accept me as if no ethnic boundaries between us". In general, similar experiences are also found in the stories of other migrants. The ability to adjust quickly to local language seems to be the key for migrants to develop bridging social capital with local people.

\section{CONCLUSION}

This article has shown that Migrants from more complex city who migrate and make livelihood in less complex city face some problems which are unique to that city both sociocultural environment and physical environment. In terms of socio-cultural problems, the migrants face problems with, at their views, low quality education in less complex and probably less developed city as well. Still in the realm of socio-cultural problems are expensiveness and language difficulties. They, in fact, can develop their adaptation well to these problems. The second core of problems they face are physical environment. There are two problems, first, related to urban density which push them to have houses in marginal urban areas with some height with a slope of about 30 to 40 degrees or areas quite far from center of the city. The second physical environment problems are the threat of frequent earthquake and volcano eruptions.

The migrants, as have been shown above, can adapt well with all the unique problems faced in the city of Ternate. There are two models of adaptations they employ. First, they take steps to solve the problems, especially the problems in socio-cultural environments. Second, they manage their knowledge, emotion, and attitude towards problems even though the real problems still exist. They change their feeling in order to see the problems as not serious, not harmful, or not problems anymore. This second adaptive strategies are used to deal with problems in physical environment which they feel they cannot change them.

\section{ACKNOWLEDGMENT}

I would like to thank the whole informants who have spent time and energy to listen and answer my various questions during the interviews. I also appreciate Ministry of Research, Technology, and higher education for support my research financially. Likewise, I appreciate Khairun University, particularly the research and community services for supporting me.

\section{REFERENCE}

[1] Z.K. Honglin and S. Song, "Rural-urban migration and urbanization in China: Evidence from time-series and cross-section analyses," China Economice Review, Volume 14, pp. 386-400, 2003. 
[2] B. Monica, "Family and Personal Networks in International Migration: Recent Developments and New Agendas," International Migration Review, Vol. 23, No. 3, pp. 638-670., 1980.

[3] M. Masja van, G. Engbersen and M. van San, "Striving for a Better Position: Aspirations and the Role of Cultural, Economic, and Social Capital for Irregular Migrants in Belgium,"The International Migration Review vol 43, No. 4, pp. 881-907, 2009.

[4] S.M. Carolyn, "Social Capital In A Mexican-American Community In Dallas, Texas," Urban Anthropology and Studies of Cultural Systems and World Economic Development vol 36, No. 4, pp. 425-456, 2007.

[5] A.M. Bernabe and D. Massey, "Social capital and the wages of Mexican migrants: New hypotheses and tests," Social Forces vol 82, No 2, pp. 671-701, 2003.
[6] A. Michael Bernabé, "The Impact of Social Capital on the Earnings of Puerto Rican Migrants," The Sociological Quarterly. Vol 46, No. 4, pp. 569-592, 2005.

[7] Z. Min and C. L. Bankston III, "Social Capital and the Adaptation of the Second Generation: The Case of Vietnamese Youthin New Orleans,'The International Migration Review. vol. 28, No. 4, pp. 821-845,1994.

[8] M. Matthew and A. M. Huberman, "Analisis Data Kualitatif," UI-Press: Jakarta, 2007

[9] A.I. Gufran, "Metamorfosa Sosial dan Kepunahan Bahasa," Lepkhair: Ternate, 2009. 